\title{
Interleukin 1 Alpha Measurement
}

National Cancer Institute

\section{Source}

National Cancer Institute. Interleukin 1 Alpha Measurement. NCI Thesaurus. Code C122131.

The determination of the amount of interleukin-1 alpha present in a sample. 